Alexander Volod kin and Gennady Zaikov

\title{
POTASSIUM AND SODIUM 2,6-DI-TERT-BUTYL PHENOXIDES AND THEIR PROPERTIES
}

\author{
N. M. Emanuel Institute of Biochemical Physics, Russian Academy of Sciences, \\ 4 Kosygina str., 119991 M oscow, Russian Federation \\ chembio@sky.chph.ras.ru
}

Received: February 24, 2009

(C) Volod'kin A., Zaikov G., 2010

\begin{abstract}
Absract. The determining factor of the reaction of 2,6di-tert-butylphenol with alkaline metal hydroxides is temperature, depending on which two types of potassium or sodium 2,6-di-tert-butyl phenoxides are formed with different catalytic activity in alkylation of 2,6-di-tertbutylphenol with methyl acrylate. More active forms of 2,6- $\mathrm{Bu}_{2} \mathrm{C}_{6} \mathrm{H}_{3} \mathrm{OK}$ or $2,6-\mathrm{Bu}_{2} \mathrm{C}_{6} \mathrm{H}_{3} \mathrm{ONa}$ are synthesized at temperatures higher than $433 \mathrm{~K}$ representing predominantly monomers of 2,6-di-tert-butylphenoxides which produce dimers when cooling. The data of $\mathrm{NMR}^{1} \mathrm{H}$, electronic, and IR spectra for the corresponding forms of 2,6- $\mathrm{Bu}_{2} \mathrm{C}_{6} \mathrm{H}_{3} \mathrm{OK}$ and 2,6- $\mathrm{Bu}_{2}{ }_{2} \mathrm{C}_{6} \mathrm{H}_{3} \mathrm{ONa}$ isolated in the individual state showed a cyclohexadienone structure. In DMSO or DMF media the dimeric forms of 2,6-ditert-butylphenoxides react with methyl acrylate to form methyl 3-(4-hydroxy-3,5-di-tert-butylphenyl) propionate with $64-92 \%$ yield.
\end{abstract}

Keywords: phenols, phenoxides, 2,6-di-tert-butylphenol, methyl acrylate, Michael reaction, kinetics, dimers, sodium hydroxide, potassium hydroxide.

\section{Introduction}

Compounds based on 2,6-di-tert-butylphenol were often used as objects of studies for development of theoretical concepts of sterically hindered phenols chemistry and for synthesis of 4-substituted phenols. Among the known reactions, those involving 2,6-di-tertbutyl phenoxides, which are reactants and catalysts in syntheses of substances with useful properties, have been poorly studied. Information on chemistry and technology of alkylation of 2,6- $\mathrm{Bu}_{2} \mathrm{C}_{6} \mathrm{H}_{3} \mathrm{OH}$ with methyl acrylate in the presence of potassium or sodium 2,6-di-tert-butyl phenoxides is predominantly concentrated in patents [15] from which it follows that 2,6- $\mathrm{Bu}_{2}{ }_{2} \mathrm{C}_{6} \mathrm{H}_{3} \mathrm{OK}$ and 2,6$\mathrm{Bu}_{2} \mathrm{C}_{6} \mathrm{H}_{3} \mathrm{ONa}$ are synthesized by the reactions of 2,6-
$\mathrm{Bu}_{2} \mathrm{C}_{6} \mathrm{H}_{3} \mathrm{OH}$ with alkaline metal alkoxides or hydroxides at elevated temperature in vacuum. It is also known that at room temperature $2,6-\mathrm{Bu}_{2} \mathrm{C}_{6} \mathrm{H}_{3} \mathrm{OH}$ does not react with alkaline metalhydroxides [6], whereas at 273-413 K the rate of this process is insufficient [7] for the preparation of 2,6-di-tert-butyl phenoxides in the individual form due to reversibility of the process. The studied reactions of 2,6-dialkyl phenoxides are described in the review [8] and publications [9-13] associated with the use of the corresponding phenoxides in the catalytic alkylation of 2,6-dialkylphenols. Despite the interest in alkylation of 2,6$\mathrm{Bu}_{2} \mathrm{C}_{6} \mathrm{H}_{3} \mathrm{OH}$, the data on the properties of individual phenoxides are insufficient, scanty, and contradictory. It remains unclear what compounds are formed in the reactions of $2,6-\mathrm{Bu}_{2}{ }_{2} \mathrm{C}_{6} \mathrm{H}_{3} \mathrm{OH}$ with alkaline metal alkoxides or hydroxides, and no data on the structure, properties, and reactivity of individual alkaline metal 2,6di-tert-butylphenoxides are available. In the patent [5] 2,6di-tert-butylphenoxides are described as monomers, whereas other literature sources $[14,15]$ show that some derivatives of 2,6-di-tert-butylphenoxides exist as dimers. Therefore, it seems of interest to reveal the true structure of 2,6- $\mathrm{Bu}_{2} \mathrm{C}_{6} \mathrm{H}_{3} \mathrm{OK}$ and 2,6- $\mathrm{Bu}_{2} \mathrm{C}_{6} \mathrm{C}_{3} \mathrm{ONa}$ and optimize the method of their synthesis. In the present work we proceed with previous studies [7] of the reactions of 2,6$\mathrm{Bu}_{2} \mathrm{C}_{6} \mathrm{H}_{3} \mathrm{OH}$ with potassium or sodium hydroxides at different temperatures and found that with the temperature increase from 433 to $473 \mathrm{~K}$ the reaction rate becomes sufficient for the formation of steam as bubbles in the reaction mixture. As a result of water evaporation, the equilibrium shifts to the formation of alkaline metal phenoxide. Under these conditions, $2,6-\mathrm{Bu}_{2}{ }_{2} \mathrm{C}_{6} \mathrm{H}_{3} \mathrm{OK}$ and $2,6-\mathrm{Bu}_{2}{ }_{2} \mathrm{C}_{6} \mathrm{H}_{3} \mathrm{ONa}$ are formed as crystals, which make it possible to isolate them in the individual state and study their properties. It turns out that the catalytic activities differ substantially for $2,6-\mathrm{Bu}_{2} \mathrm{C}_{6} \mathrm{H}_{3} \mathrm{OK}$ synthesized by the reaction of 2,6- $\mathrm{Bu}_{2}{ }_{2} \mathrm{C}_{6} \mathrm{H}_{3} \mathrm{OH}$ with $\mathrm{KOH}$ at $453-473 \mathrm{~K}$ and the material obtained from $2,6-\mathrm{Bu}_{2} \mathrm{C}_{6} \mathrm{H}_{3} \mathrm{OH}$ and 
$\mathrm{Bu}^{\mathrm{t}} \mathrm{OK}$ in $\mathrm{Bu}^{\mathrm{t}} \mathrm{OH}$ when the solvent is removed in vacuum at $\sim 373 \mathrm{~K}$. The process at $373-413 \mathrm{~K}$ produces a uniform gel-like mixture consisting of 2,6-di-tert-butylphenol, the corresponding phenoxide, and alkaline metal hydroxide.

\section{Experimental}

NMR ${ }^{1} \mathrm{H}$ spectra were recorded on a Bruker WM-400 instrument (400 MHz) in DMSO-d 6 (99.5\%) signals of the solvent as internal standard. The integral intensity from the water peak was less than $5 \%$ of the integral intensity of residual protons of DMSO- $\mathrm{d}_{6}$ signals. IR spectra were obtained on a Perkin-Elmer 1725-X spectrometer in $\mathrm{KBr}$ pellets (resolution $2 \mathrm{~cm}^{-1}$ ). Electronic spectra were measured on a Shimadzu UV-3101 PC instrument. Molecular weights were determined by the thermoelectric method using a cell described previously [16] and calculated by the formula:

$$
M=\frac{k \cdot g \cdot M_{s}}{100\left(t_{1}-t_{2}\right)}
$$

where $g$ is a weighed sample per $100 \mathrm{~g}$ of solvent (2$3 \%), k$ is the coefficient of the instrument and thermistors, $M_{S}$ is the molecular weight of a standard sample, and $\left(t_{1}-t_{2}\right)$ is the value equivalent to the temperature change in the cell filled with a sample solution by the potentiometer scale. The temperature in the thermostat was $355 \mathrm{~K}$. Kinetic data were obtained by liquid chromatography of reaction mixtures (Bruker LC-31 chromatograph, IBM Cyano column, hexane-isopropyl alcohol ethyl acetate $(8: 1: 1, \mathrm{v} / \mathrm{v})$ mixture as eluent, rate $0.4 \mathrm{ml} \cdot \mathrm{min}^{-1}$ ).

\subsection{Potassium 2,6-Di-tert-Butyl Phenoxide}

A. A flask was filled with 2,6- $\mathrm{Bu}_{2}{ }_{2} \mathrm{C}_{6} \mathrm{H}_{3} \mathrm{OH}$ (20.6 $\mathrm{g}, 0.1 \mathrm{~mol}$ ) and heated in an argon flow to $463 \mathrm{~K}$, and granulated $(85 \%) \mathrm{KOH}(1.5 \mathrm{~g})$ was added. After $10 \mathrm{~min}$ the crystals that formed were separated by hightemperature filtration under argon and washed with $n$-octane heated to $383-388 \mathrm{~K}$ until no $2,6-\mathrm{Bu}_{2} \mathrm{C}_{6} \mathrm{H}_{3} \mathrm{OH}$ was found in the mother liquor. Residues of the solvent were separated in vacuum at $393-403 \mathrm{~K}$ to obtain 2,6$\mathrm{Bu}_{2} \mathrm{C}_{6} \mathrm{H}_{3} \mathrm{OK}$ (5.3 g, $93.5 \%$ ), which was placed under argon into a flask heated to $393-403 \mathrm{~K}$. NMR ${ }^{1} \mathrm{H}, \delta: 1.30$ $(\mathrm{s}, 18 \mathrm{H}) ; 5.58(\mathrm{t}, 1 \mathrm{H}, \mathrm{J}=6 \mathrm{~Hz}) ; 6.58(\mathrm{~d}, 2 \mathrm{H}, \mathrm{J}=6 \mathrm{~Hz})$. NMR ${ }^{1} \mathrm{H}$ spectrum of 2,6-di-tert-butylphenol (for comparison), $\delta: 1.37(\mathrm{~s}, 18 \mathrm{H}) ; 3.48(\mathrm{~s}, 1 \mathrm{H}) ; 6.74(\mathrm{t}, 1 \mathrm{H}$, $\mathrm{J}=8 \mathrm{~Hz}) ; 7.06(\mathrm{~d}, 2 \mathrm{H}, \mathrm{J}=8 \mathrm{~Hz}) . \mathrm{IR}, \mathrm{v} / \mathrm{cm}^{-1}: 1657,1633$ ( $-\mathrm{C}=\mathrm{C}-\mathrm{C}=\mathrm{O}$, monomer $) ; 1601(-\mathrm{C}=\mathrm{C}-\mathrm{C}=\mathrm{O}$, dimer $)$; 1574 ( $-\mathrm{C}=\mathrm{C}-$, aromatic structure) (Fig. 1a). Found: $M_{\min }=260$. Calculated for $2,6-\mathrm{Bu}_{2} \mathrm{C}_{6} \mathrm{H}_{3} \mathrm{OK}: M=$ $=244.28$. Upon heating the crystals above $493 \mathrm{~K}$ they are partially decomposed with the release of isobutylene. When this product is treated with $10 \% \mathrm{HCl}$, the $\mathrm{LC}$ analysis shows the presence of 2-tert-butylphenol.

B. A flask was filled with 2,6- $\mathrm{Bu}_{2}{ }_{2} \mathrm{C}_{6} \mathrm{H}_{3} \mathrm{OH}$ (20.6 $\mathrm{g}, 0.1 \mathrm{~mol}$ ) and heated in an argon flow to $463 \mathrm{~K}$, and granulated $(85 \%) \mathrm{KOH}(1.5 \mathrm{~g})$ was added. After $10 \mathrm{~min}$ the reaction mixture as a suspension was cooled to $\sim 293 \mathrm{~K}$, and heptane $(50 \mathrm{ml})$ was added. The precipitate was filtered off and washed with heptane until no $2,6-\mathrm{Bu}_{2} \mathrm{C}_{6} \mathrm{H}_{3} \mathrm{OH}$ was found in the washing solutions to obtain $5.1 \mathrm{~g}(90 \%)$ of $2,6-\mathrm{Bu}_{2} \mathrm{C}_{6} \mathrm{C}_{6} \mathrm{H}_{3} \mathrm{OK}$. Its NMR ${ }^{1} \mathrm{H}$ spectrum is identical to that recorded for the sample synthesized using method A. IR, v/ $/ \mathrm{cm}^{-1}: 1657,1633(-\mathrm{C}=\mathrm{C}-\mathrm{C}=\mathrm{O}$, monomer $)$; $1601(-\mathrm{C}=\mathrm{C}-\mathrm{C}=\mathrm{O}$, dimer $) ; 1574(-\mathrm{C}=\mathrm{C}-$, aromatic structure) (Fig. 1b). UV, $\lambda_{\text {max }} / \mathrm{nm}(\log \varepsilon): 320$ (3.48) (DMSO solvent); 317 (3.72) (DMF solvent). Found (\%): C, 68.54; $\mathrm{H}, 8.40 ; \mathrm{K}, 16.25 . \mathrm{C}_{14} \mathrm{H}_{21} \mathrm{KO}$. Calculated (\%): C, 68.79; H, 8.66; K, 16.00. Found: $M_{\text {max }}=480$. Calculated for 2,6$\mathrm{Bu}_{2} \mathrm{C}_{6} \mathrm{H}_{3} \mathrm{OK}: M=244.28$. When cooling the 2,6$\mathrm{Bu}_{2} \mathrm{C}_{6} \mathrm{H}_{3} \mathrm{OK}$ sample synthesized by method $\mathrm{A}$, the intensity of the bands in the IR spectrum at 1700 $1300 \mathrm{~cm}^{-1}$ changes below $\sim 293 \mathrm{~K}$, and the spectrum becomes identical to that recorded for the sample obtained using method $\mathrm{B}$.

\subsection{Sodium 2,6-Di-tert-Butylphenoxide}

Sodium 2,6-di-tert-butylphenoxide was synthesized similarly to method $\mathrm{B}$ with $86 \%$ yield. NMR ${ }^{1} \mathrm{H}, \delta: 1.30$ $(\mathrm{s}, 18 \mathrm{H}) ; 5.59(\mathrm{t}, 1 \mathrm{H}, \mathrm{J}=6 \mathrm{~Hz}) ; 6.57(\mathrm{~d}, 2 \mathrm{H}, \mathrm{J}=6 \mathrm{~Hz})$. IR, $v / \mathrm{cm}^{-1}: 1656,1633$ ( $-\mathrm{C}=\mathrm{C}-\mathrm{C}=\mathrm{O}$, monomer); 1601 $(\mathrm{C}=\mathrm{C}-\mathrm{C}=\mathrm{O}$, dimer $) ; 1565 \quad(-\mathrm{C}=\mathrm{C}-$, aromatic structure). UV, $\lambda_{\max } / \mathrm{nm}(\log \varepsilon): 320$ (3.55) (solvent DMSO); 322 (3.48) (solvent DMF). Found (\%):C, 73.54; $\mathrm{H}, 9.40 ; \mathrm{Na}, 10.25 . \mathrm{C}_{14} \mathrm{H}_{21} \mathrm{NaO}$. Calculated (\%): C, 73.65; H, 9.28; Na, 10.07. Found: $M_{\max }=458$. Calculated for 2,6- $\mathrm{Bu}_{2} \mathrm{C}_{6} \mathrm{H}_{3} \mathrm{ONa}: M=228.96$.

\subsection{M ethyl 3-(4-Hydroxy-3,5-Di-tert- Butylphenyl) Propionate}

A. Methyl acrylate $(2.5 \mathrm{ml}, 0.03 \mathrm{~mol})$ was added in an argon flow to a solution of $2,6-\mathrm{Bu}_{2}{ }_{2} \mathrm{C}_{6} \mathrm{H}_{3} \mathrm{OK}$ $(4.88 \mathrm{~g}, 0.01 \mathrm{~mol})$, which was synthesized by method $\mathrm{B}$, in DMSO $(9.4 \mathrm{ml})$ at $388 \mathrm{~K}$. After $3 \mathrm{~h}$ the reaction mixture was cooled to $\sim 293 \mathrm{~K}, 10 \% \mathrm{HCl}$ was added to neutral $\mathrm{pH}$, and the product was extracted with hexane. Methyl 3-(4-hydroxy-3,5-di-tert-butylphenyl) propionate was obtained with the yield of $5.16 \mathrm{~g}(88 \%$ ), m.p. $339 \mathrm{~K}$ (cf. [9]: m.p. 388 K). When DMSO was replaced with DMF, the yield of the product became $92 \%$. When 2,6$\mathrm{Bu}_{2} \mathrm{C}_{6} \mathrm{C}_{3} \mathrm{ONa}$ in an equivalent amount $(4.56 \mathrm{~g}$ ) was used instead of $2,6-\mathrm{Bu}_{2} \mathrm{C}_{6} \mathrm{H}_{3} \mathrm{OK}$ in DMSO, the product yield was $64 \%$ (LC data). 


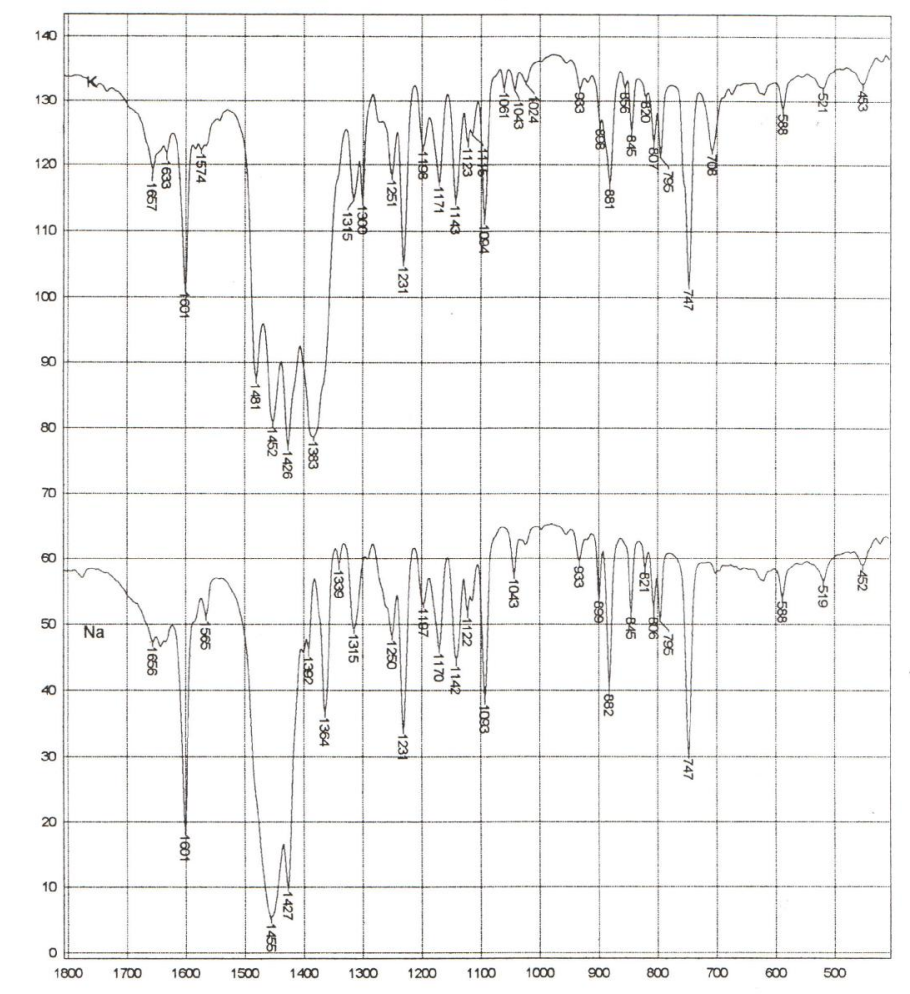

Transmittance / Wavenumber (cm-1)

Fig. 1. IR spectra of the monomer and dimer of potassium 2,6-di-tert-butyl phenoxide synthesized by methods A and $\mathrm{B}$, respectively

B. Granulated $\mathrm{KOH}(0.11 \mathrm{~g}, 0.002 \mathrm{~mol})$ was added in an argon flow to 2,6- $\mathrm{Bu}_{2} \mathrm{C}_{6} \mathrm{H}_{3} \mathrm{OH}(20.6 \mathrm{~g}$, $0.1 \mathrm{~mol}$ ) heated to $463 \mathrm{~K}$. After $10 \mathrm{~min}$ the reaction mixture was cooled to $403 \mathrm{~K}$, and methyl acrylate $(11 \mathrm{~g}, 0.13$ mol) was added. After the reactants were mixed, the temperature of the reaction mixture decreased to $383 \mathrm{~K}$. After 25 min the content of the product in the reaction mixture was $98 \mathrm{~mol} \%$.

C. Methyl acrylate $(11 \mathrm{~g}, 0.13 \mathrm{~mol})$ was added in an argon flow at $383 \mathrm{~K}$ to a mixture of $2,6-\mathrm{Bu}_{2}{ }_{2} \mathrm{C}_{6} \mathrm{H}_{3} \mathrm{OH}$ $(20.6 \mathrm{~g}, 0.1 \mathrm{~mol})$ and $2,6-\mathrm{Bu}_{2}{ }_{2} \mathrm{C}_{6} \mathrm{H}_{3} \mathrm{OK}(0.488 \mathrm{~g}, 0.002$ mol) synthesized by method B. After 25 min the content of the product in the reaction mixture became $15 \mathrm{~mol} \%$, while after $3 \mathrm{~h}$ it reached $87 \%$. Similarly, when 2,6$\mathrm{Bu}_{2}{ }_{2} \mathrm{C}_{6} \mathrm{H}_{3} \mathrm{ONa}(0.456 \mathrm{~g}, 0.002 \mathrm{~mol})$ synthesized by method $\mathrm{B}$ was used, the product yield after $3 \mathrm{~h}$ became $72 \%$.

\section{Results and Discussion}

2,6-Di-tert-butylphenol does not react with alkaline metal hydroxides at room temperature, whereas on heating to $413 \mathrm{~K}$ the acid-base equilibrium is achieved with a low rate and shifts to the initial components [7]. However, at higher temperatures $(453-473 \mathrm{~K})$ the reaction rate is sufficient for steam bubbles to form in a solution of 2,6di-tert-butylphenol, which favors their removal from the reaction mixture and the shift of equilibrium. The reaction proceeds within a short time $(5-10 \mathrm{~min})$ and is accompanied by the formation of potassium or sodium 2,6-di-tert-butyl phenoxide as crystals. The study of 2,6$\mathrm{Bu}_{2} \mathrm{C}_{6} \mathrm{H}_{3} \mathrm{OK}$ and 2,6- $\mathrm{Bu}_{2} \mathrm{C}_{6} \mathrm{H}_{3} \mathrm{ONa}$ isolated in the individual state found that they can exist as both monomers and dimers. At high temperature a monomer is formed and spontaneously transformed into a more stable dimeric form with the temperature decrease. The conclusion about the existence of two forms of the corresponding phenoxides is based on the results of measurements of the molecular weights, IR spectroscopic data, and observation of different catalytic activities in the reaction of $2,6-\mathrm{Bu}_{2}{ }_{2} \mathrm{C}_{6} \mathrm{H}_{3} \mathrm{OH}$ with methyl acrylate. To retain the primary properties of the monomeric forms of 2,6- $\mathrm{Bu}_{2}{ }_{2} \mathrm{C}_{6} \mathrm{H}_{3} \mathrm{OK}$ or $2,6-\mathrm{Bu}_{2} \mathrm{C}_{6} \mathrm{H}_{3} \mathrm{ONa}$ phenoxides from the moment of formation to the corresponding measurements, we proposed a method for conservation of a sample by storage in a flask under argon at 393$403 \mathrm{~K}$. In the IR spectra of the samples obtained by 
methods $\mathrm{A}$ and $\mathrm{B}$ (monomer and dimer, respectively), the most informative is the region from 1700 to $1300 \mathrm{~cm}^{-1}$ containing the characteristic bands at 1633 and $1656 \mathrm{~cm}^{-1}$ (typical of the conjugated carbonyl group of quinolide compounds) and at $1601 \mathrm{~cm}^{-1}$. It is known [17] that the band at $1601 \mathrm{~cm}^{-1}$ is present in the IR spectrum of the dimer of 4-bromo-2,6-di-tert-butyl-4methylcyclohexa-2,5-dienone, and it has earlier been assigned to the carbonyl group of the quinobromide compound in the dimer structure.

In the IR spectra of the considered samples, the bands at 1633,1656 and $1601 \mathrm{~cm}^{-1}$ differ in intensity. For $2,6-\mathrm{Bu}_{2} \mathrm{C}_{6} \mathrm{H}_{3} \mathrm{OK}$ monomer the intensity of the bands at $1633,1655 \mathrm{~cm}^{-1}$ is much higher, whereas in the spectra of 2,6- $\mathrm{Bu}_{2} \mathrm{t}_{2} \mathrm{C}_{6} \mathrm{H}_{3} \mathrm{OK}$ the high-intensity band lies at $1601 \mathrm{~cm}^{-1}$. The band at $1574 \mathrm{~cm}^{-1}$, which belongs to $\mathrm{C}=\mathrm{C}$ bond of aromatic compounds [18], has a low intensity in the spectra. The frequency region of $1475-1300 \mathrm{~cm}^{-1}$ usually remains uninterpreted; however, it contains bands for the most part of quinolide compounds and methylene quinones. The NMR ${ }^{1} \mathrm{H}$ spectra of potassium and sodium 2,6-di-tert-butyl phenoxides in DMSO- $\mathrm{d}_{6}$ show that signals from the meta- and para-protons lie at $\delta=6.58$ and 5.58, respectively, which corresponds to the region of olefinic protons. Compared to the spectrum of the initial 2,6-ditert-butylphenol, these signals exhibit noticeable upfield shift. This result confirms that molecules of potassium and sodium 2,6-di-tert-butyl phenoxides in solution exist in the quinolide form. The shape of the electronic spectra of dimers of potassium and sodium 2,6-di-tert-butyl phenoxides in DMSO changes in time, which indicates, probably, the interaction of phenoxides with a polar aprotic solvent. The absorbance of the bands begins to change from the moment of the solution preparation and continues during 4-6 h. This is accompanied by a decrease in the absorbance of the band with $\lambda_{\max }=320 \mathrm{~nm}$ and an increase in the absorbances of the bands with $\lambda_{\max }=260$ and $481 \mathrm{~nm}$, and these changes pass through the isosbestic points (Fig. 2). It can be assumed that in DMSO solution $2,6-\mathrm{Bu}_{2}{ }_{2} \mathrm{C}_{6} \mathrm{H}_{3} \mathrm{OK}$ dimer (band with $\lambda_{\max }=320 \mathrm{~nm}$ ) decomposes to form an ambidentate ion $\left(\lambda_{\max }=260 \mathrm{~nm}\right)$ and a complex with the solvent $\left(\lambda_{\max }=481 \mathrm{~nm}\right)$. The broad band with $\lambda_{\max }=767 \mathrm{~nm}$ is present in the initial spectrum of 2,6- $\mathrm{Bu}_{2}{ }_{2} \mathrm{C}_{6} \mathrm{H}_{3} \mathrm{OK}$ and retains during transformation of the electronic spectrum with time. This fact can be related to vibrations of the metal cation in a molecule of 2,6$\mathrm{Bu}_{2} \mathrm{C}_{6} \mathrm{H}_{3} \mathrm{OK}$ dimer or $2,6-\mathrm{Bu}_{2} \mathrm{C}_{6} \mathrm{H}_{3} \mathrm{OK}$ complex with the solvent. Their amplitude is sufficient for the formation of the electronic spectrum at $\lambda=767 \mathrm{~nm}$. The time dependence of the absorbance of the band with $\lambda_{\max }=320-317 \mathrm{~nm}$ is linear and characterized by the $k_{l}$ constant depending on the solvent nature.
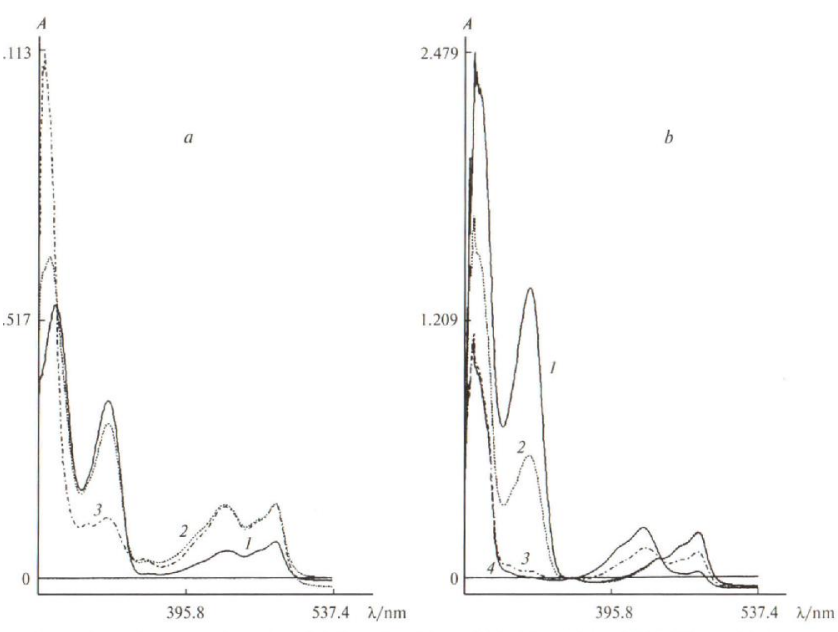

Fig. 2. Changes in the electronic spectra of potassium 2,6-di-tert-butyl phenoxide in solutions of DMSO (a) and

DMF (b); a: initial spectrum (1), spectrum in 48 (2) and $352 \mathrm{~min}$ (3) after dissolution;

b: initial spectrum (1), spectrum in 37 (2), 118 (3), and $181 \mathrm{~min}(4)$ after dissolution

Similar results were obtained for the electronic spectra of sodium 2,6-di-tert-butylphenoxide in DMSO and DMF solutions. The initial spectrum of the 2,6$\mathrm{Bu}_{2} \mathrm{C}_{6} \mathrm{H}_{3} \mathrm{ONa}$ dimer contains bands with $\lambda_{\text {max }}=320 \mathrm{~nm}$ (DMSO) and $322 \mathrm{~nm}$ (DMF), which undergo transformations at $478-481 \mathrm{~nm}$. Taking into account the obtained results, it seemed of interest to study regularities of the Michael reactions between 2,6- $\mathrm{Bu}_{2}{ }_{2} \mathrm{C}_{6} \mathrm{H}_{3} \mathrm{OK}$ and $2,6-\mathrm{Bu}_{2} \mathrm{t}_{6} \mathrm{C}_{6} \mathrm{H}_{3} \mathrm{ONa}$ dimers and methyl acrylate in polar solvents, for instance, DMSO and DMF. It turned out that in these solvents the main direction is the reaction of alkaline metal 2,6-di-tert-butyl phenoxides with methyl acrylate affording methyl 3-(4-hydroxy-3,5-di-tertbutylphenyl)propionate. In the absence of solvent, the main direction is methyl acrylate polymerization [11]. The kinetics of the reaction of 2,6- $\mathrm{Bu}_{2} \mathrm{C}_{6} \mathrm{H}_{3} \mathrm{OK}$ dimer with methyl acrylate was studied in DMSO and DMF solutions. Comparing the experimental and calculated data for the kinetic scheme with account for the decomposition of 2,6- $\mathrm{Bu}_{2} \mathrm{C}_{6} \mathrm{H}_{3} \mathrm{OK}$ dimer in polar solvents, we calculated the apparent rate constants $\left(k_{2}\right)$ of the reaction of $\mathrm{ArOK}-$ Solv complexes (Solv is solvent) with methyl acrylate (Scheme 1).

Using Scheme 1, we performed the mathematical simulation of the experimental kinetic data for ArOK accumulation taking into account $k_{1}=7.5 \cdot 10^{-5} \mathrm{~s}^{-1}$, which was determined from the plot of the decrease in the absorbance of the band with $\lambda_{\max }=320 \mathrm{~nm}$ of 2,6$\mathrm{Bu}_{2} \mathrm{C}_{6} \mathrm{H}_{3} \mathrm{OK}$ dimer in DMSO. The program for calculation of the reaction kinetics based on the solution of the "rigid system" of differential equations was used in mathematical simulation. The experimental data and calculated curve are shown in Fig. 3. 


$$
\begin{aligned}
& \left(2,6-\mathrm{Bu}_{2}^{\mathrm{t}} \mathrm{C}_{6} \mathrm{H}_{3} \mathrm{OK}\right)+\mathrm{Solv} \underset{\mathrm{k}_{-1}}{\stackrel{\mathrm{k}_{1}}{\rightleftharpoons}} 2\left(2,6-\mathrm{Bu}_{2}^{\mathrm{t}} \mathrm{C}_{6} \mathrm{H}_{3} \mathrm{OK}\right)--\mathrm{Solv} \\
& 2\left(2,6-\mathrm{Bu}_{2}^{\mathrm{t}} \mathrm{C}_{6} \mathrm{H}_{3} \mathrm{OK}\right)--\mathrm{Solv}+\mathrm{MA} \underset{\mathrm{k}_{-2}}{\rightleftharpoons} 2,6-\mathrm{Bu}_{2}^{\mathrm{t}} \mathrm{C}_{6} \mathrm{H}_{3} \mathrm{OK}^{---} \mathrm{MA}+\text { Solv } \\
& 2,6-\mathrm{Bu}_{2}^{\mathrm{t}} \mathrm{C}_{6} \mathrm{H}_{3} \mathrm{OK}----\mathrm{MA} \stackrel{\mathrm{k}_{3}}{\longrightarrow} \mathrm{Ar} \mathrm{OK} \\
& \mathrm{ArOK}+\mathrm{H}^{+} \longrightarrow \mathrm{ArOH}
\end{aligned}
$$

MA is methyl acrylate, ArOH is methyl-3-(4hydroxy-3,5-di-tert-butylphenyl)propionate

\section{Scheme 1}

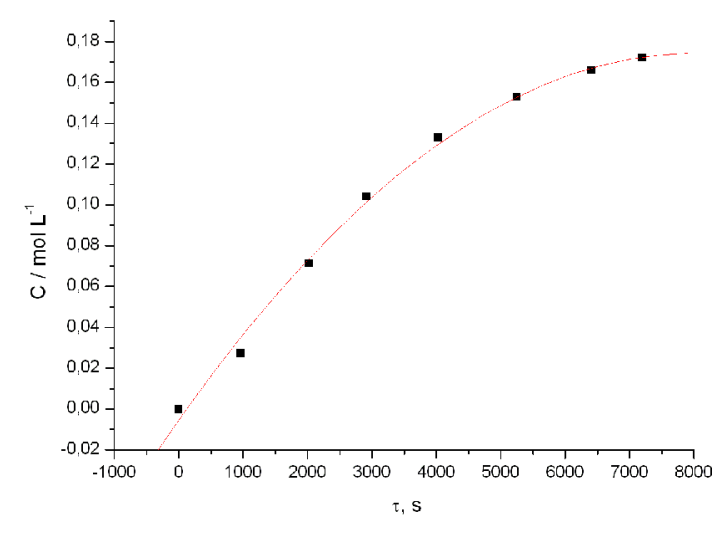

Fig. 3. Experimental data (points) and results of calculation (curve) of the kinetics of formation of potassium methyl 3-(4-hydroxy-3,5-di-tert-butylphenyl) propionate in the reaction of the potassium 2,6-di-tert-butyl phenoxide dimer with methyl acrylate in DMSO solution; $C$ is the concentration of potassium methyl 3-(4-hydroxy-3,5-di-tertbutylphenyl) propionate; $\left[\left(2,6-\mathrm{Bu}_{2} \mathrm{C}_{6} \mathrm{C}_{3} \mathrm{OK}\right)_{2}\right]_{0}=0.01 \mathrm{~mol} \cdot \mathrm{l}^{-1}$,

$[\mathrm{MA}]_{0}=0.3 \mathrm{~mol} \cdot \mathrm{l}^{-1},[\mathrm{DMSO}]_{0}=12 \mathrm{~mol} \cdot \mathrm{l}^{-1}, 388 \mathrm{~K}$

The results of calculation of the parameters $\left(k_{l}\right.$, $\mathrm{s}^{-1} ; k_{2}, 1 \cdot \mathrm{mol}^{-1} \cdot \mathrm{s}^{-1} ; k_{-}, 1 \cdot \mathrm{mol}^{-1} \cdot \mathrm{s}^{-1}$ and $\left.k_{3}\right)$ for $[2,6-$ $\left.\mathrm{Bu}_{2} \mathrm{C}_{6} \mathrm{H}_{3} \mathrm{OK}\right]_{2}$ (I), MA (II), and solvent (III) are given below:

\begin{tabular}{|c|c|c|c|c|c|c|c|}
\hline \multirow{2}{*}{ Solvent } & \multicolumn{3}{|c|}{$C_{0}, \mathrm{~mol}^{-1} \mathrm{l}^{-1}$} & \multirow{2}{*}{$k_{l} \cdot 10^{-4}$} & \multirow{2}{*}{$k_{2} \cdot 10^{-3}$} & $k_{-} \cdot 10^{-5}$ & $k_{3} \cdot 10^{-3}$ \\
\cline { 2 - 8 } & I & II & III & & & & \\
\hline DMSO & 0.1 & 0.3 & 12 & 0.75 & 2.3 & 4 & 6 \\
\hline DMF & 0.1 & 0.3 & 12 & 3.8 & 6.3 & 4 & 2 \\
\hline
\end{tabular}

The calculation of the kinetic scheme of the reaction of methyl acrylate with $2,6-\mathrm{Bu}_{2} \mathrm{C}_{6} \mathrm{H}_{3} \mathrm{ONa}$ and DMF gives the following reaction rate constants: $k_{1}=9.1 \cdot 10^{-4} \cdot \mathrm{s}^{-1}$, $k_{2}=9.7 \cdot 10^{-4}, k_{-}{ }_{2}=7.4 \cdot 10^{-4} 1 \cdot \mathrm{mol}^{-1} \cdot \mathrm{s}^{-1}$, and $k_{3}=8.2 \cdot 10^{-3}$. Alkaline metal 2,6-di-tert-butyl phenoxides can be added to methyl acrylate as stoichiometric reactants. It was of interest to use them as catalysts of the reactions of 2,6$\mathrm{Bu}_{2} \mathrm{C}_{6} \mathrm{H}_{3} \mathrm{OH}$ with methyl acrylate. It turned out that the catalytic properties of 2,6-di-tert-butyl phenoxides in this
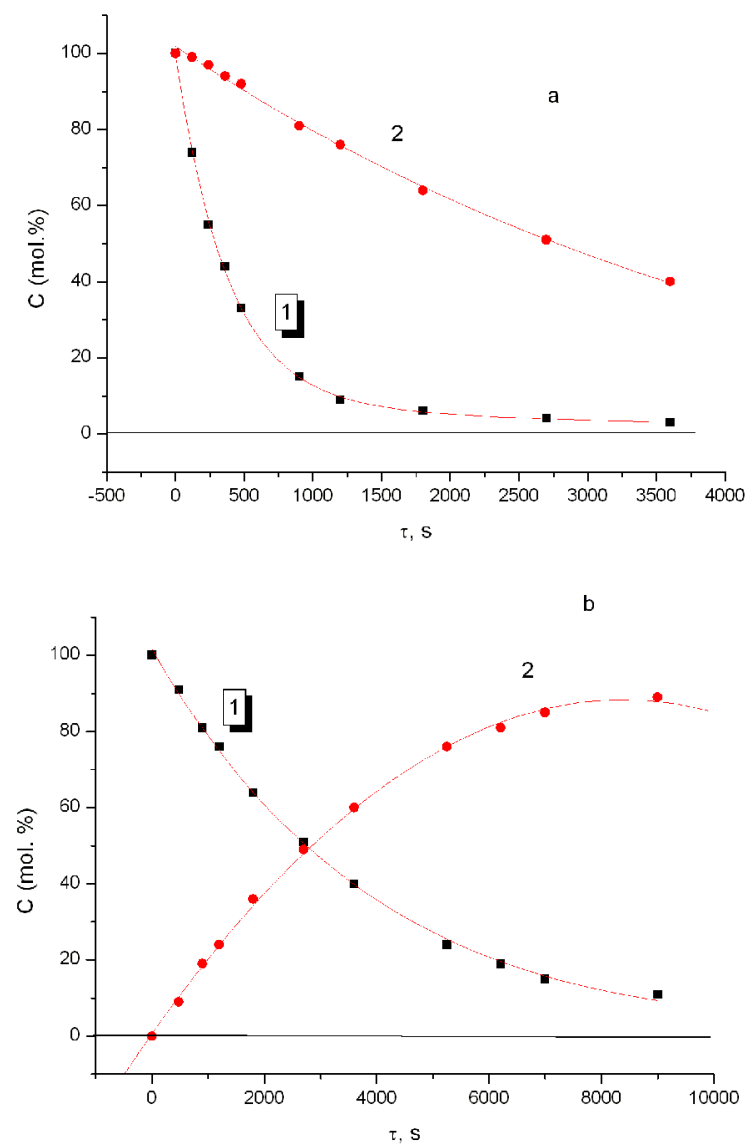

Fig. 4. Kinetics of consumption of $2,6-\mathrm{Bu}_{2} \mathrm{C}_{6} \mathrm{C}_{3} \mathrm{OH}$ in the catalytic reaction with methyl acrylate in the presence of the monomer and dimer of $2,6-\mathrm{Bu}_{2} \mathrm{C}_{6} \mathrm{H}_{3} \mathrm{OK}$ (a) and 2,6- $\mathrm{Bu}_{2} \mathrm{t}_{6} \mathrm{C}_{6} \mathrm{H}_{3} \mathrm{OK}$ synthesized from 2,6- $\mathrm{Bu}_{2} \mathrm{t}_{6} \mathrm{C}_{6} \mathrm{H}_{3} \mathrm{OH}$ and $\mathrm{Bu}^{\mathrm{t}} \mathrm{OK}(\mathrm{b})$

a: 1 - monomer; $[\mathrm{ArOH}]_{0}=3.29 \mathrm{~mol} \cdot \mathrm{l}^{-1}$,

$[\mathrm{MA}]_{0}=3.75 \mathrm{~mol} \cdot \mathrm{l}^{-1},[\mathrm{ArOK}]_{0}=0.066 \mathrm{~mol} \cdot \mathrm{l}^{-1}, 388 \mathrm{~K}$;

2 - dimer; $\left(2,6-\mathrm{Bu}_{2}{ }_{2} \mathrm{C}_{6} \mathrm{H}_{3} \mathrm{OK}\right)_{2}$ dimer synthesized from 2,6$\mathrm{Bu}_{2}{ }_{2} \mathrm{C}_{6} \mathrm{H}_{3} \mathrm{OH}$ and $\mathrm{KOH}$ at $463 \mathrm{~K}$ and isolated at $293 \mathrm{~K}$, temperature of alkylation $388 \mathrm{~K} ;[\mathrm{ArOH}]_{0}=3.29 \mathrm{~mol} \cdot \mathrm{l}^{-1}$,

$[\mathrm{MA}]_{0}=3.75 \mathrm{~mol} \cdot \mathrm{l}^{-1},\left[(\mathrm{ArOK})_{2}\right]_{0}=0.05 \mathrm{~mol} \cdot \mathrm{l}^{-1}$;

b: 1 - kinetics of consumption of $2,6-\mathrm{Bu}_{2} \mathrm{t}_{2} \mathrm{C}_{6} \mathrm{H}_{3} \mathrm{OH}$;

2 - kinetics of formation of methyl 3-(4-hydroxy-3,5-di-tertbutylphenyl) propionate 
reaction depend on the method of their preparation (method A or B). 2,6- $\mathrm{Bu}_{2} \mathrm{C}_{6} \mathrm{H}_{3} \mathrm{OK}$ dimer (method $\mathrm{B}$ ) is similar in catalytic activity to the product of the reaction of 2,6-di-tert-butylphenol with potassium tert-butoxide, whereas 2,6- $\mathrm{Bu}_{2} \mathrm{C}_{6} \mathrm{H}_{3} \mathrm{OK}$ monomer (method $\mathrm{A}$ ) is the most efficient between known catalysts. When the content of 2,6- $\mathrm{Bu}_{2} \mathrm{C}_{6} \mathrm{H}_{3} \mathrm{OK}$ monomer is 1.5-3.0 mol \% of the content of $2,6-\mathrm{Bu}_{2} \mathrm{C}_{6} \mathrm{H}_{3} \mathrm{OH}$ at $383-388 \mathrm{~K}$, the reaction ceases within 15-20 min to form $\mathrm{ArOH}$ with up to $98 \%$ yield (Fig. 4a). Under similar conditions, the reaction of potassium 2,6-di-tert-butyl phenoxide synthesized in situ from $2,6-\mathrm{Bu}_{2} \mathrm{C}_{6} \mathrm{H}_{3} \mathrm{OH}$ and potassium tert-butoxide (> $5 \mathrm{~mol} \%$ ) proceeds within 2.5-3 h to form $\mathrm{ArOH}$ with the yield of at most $85 \%$ (Fig. 4b). The catalytic properties of the monomeric forms of 2,6- $\mathrm{Bu}_{2} \mathrm{C}_{6} \mathrm{H}_{3} \mathrm{ONa}$ and 2,6$\mathrm{Bu}_{2} \mathrm{C}_{6} \mathrm{H}_{3} \mathrm{OK}$ are similar, whereas the reaction of 2,6$\mathrm{Bu}_{2} \mathrm{t}_{6} \mathrm{H}_{3} \mathrm{OH}$ with methyl acrylate in the presence of 2,6$\mathrm{Bu}_{2} \mathrm{C}_{6} \mathrm{H}_{3} \mathrm{ONa}$ dimers proceeds with a lower rate.

\section{Conclusions}

Thus, we found that the catalytic properties of potassium (sodium) 2,6-di-tert-butyl phenoxides depend on the temperature of their synthesis by the reaction of 2,6-di-tert-butylphenol with alkaline metal hydroxides. Methyl 3-(4-hydroxy-3,5-di-tert-butylphenyl) propionate is formed predominantly in the reaction of 2,6$\mathrm{Bu}_{2} \mathrm{C}_{6} \mathrm{H}_{3} \mathrm{OK}$ or $2,6-\mathrm{Bu}_{2} \mathrm{C}_{6} \mathrm{H}_{3} \mathrm{ONa}$ dimer with methyl acrylate in DMSO and DMF solutions. The data obtained indicate, possibly, that charge separation with electron density distribution between the $\mathrm{O}$ atom and $\mathrm{C}$ atoms of the cyclohexadienone structure occurs in a molecule of potassium and sodium 2,6-di-tert-butyl phenoxides. A consequence of polarization of phenoxide molecules is their capability of dimerizing and interacting with metal cations through double bonding with $\mathrm{O}$ and $\mathrm{C}$ atoms of the six-membered ring involving two phenoxide molecules. As follows from the atomic model of the dimer (Fig. 5), the oxygen and metal atoms are spatially shielded by the

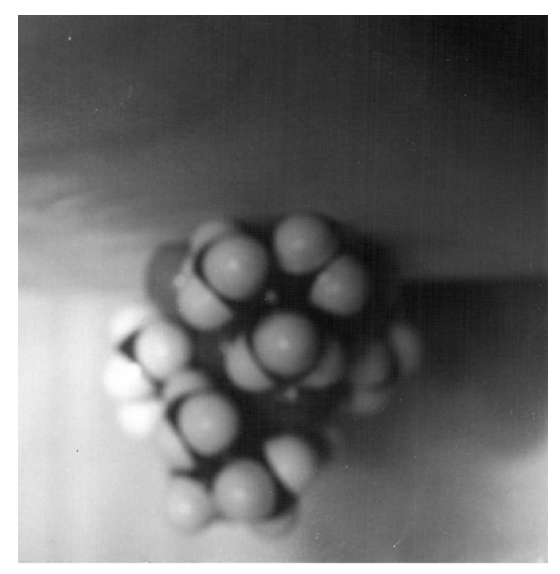

Fig. 5. Atomic model of the alkaline metal 2,6-di-tert-butyl phenoxide dimer tert-butyl substituents, and their intramolecular arrangement favors the interaction of the metal cations with $\mathrm{O}$ and $\mathrm{C}$ atoms of two six-membered rings. The monomeric form of $2,6-\mathrm{Bu}_{2} \mathrm{C}_{6} \mathrm{H}_{3} \mathrm{OK}$ or $2,6-\mathrm{Bu}_{2}{ }_{2} \mathrm{C}_{6} \mathrm{H}_{3} \mathrm{ONa}$ phenoxides is presented by the nonassociated, more reactive metal cation, which just predetermines their higher catalytic properties.

\section{References}

[1] US Pat. 3277148, Chem. Abstrs, 1966, 65, 18535.

[2] US Pat. 3526668, Chem. Abstrs, 1970, 73, 98589.

[3] Jpn Pat. 161350, Chem. Abstrs, 1982, 96, 162344.

[4] US Pat. 5264612, Chem. Abstrs, 1993, 120, 191356.

[5] US Pat. 5177247, Chem. Abstrs, 1993, 116, 6249.

[6] Stillson G.: J. Am. Chem. Soc., 1946, 68, 722.

[7] Volod'kin A. and Zaikov G.: Russ. Chem. Bull., Int. Ed., 2002, 51, 2189.

[8] Volod'kin A. and Zaikov G.: Mendeleev Chem. J., 2000, 44, 81. [9] Volod'kin A., Paramonov V., Egidis F. and Popov L.: Khim. Promyshlennost., 1988, 12, 7.

[10] Volod'kin A.: Russ. Chem. Bull., 1994, 43, 769.

[11] Volod'kin A., Zaitsev A., Rubailo V. et al.: Izv. Akad. Nauk SSSR, Ser. Khim., 1989, 1829.

[12] Titova T., Krysin A., Bulgakov V. and Mamatyuk V.: Zh. Org. Khim,, 1984, 20, 1899.

[13] Bulgakov V., Gorodetskaya N., Nikiforov G. and Ershov V.: Izv. Akad. Nauk SSSR, Ser. Khim., 1983, 71.

[14] Shobatake K. and Nakamoto K.: J. Inorg. Chem. Acta, 1970, 4, 485.

[15] Muller E., Ziemek P. and Rieker A.: Tetrahedron Lett., 1964, 4, 207.

[16] Bekhli E., Novikov D. and Entelis S.: Vysokomolek. Soedin. A, 1967, 9, 2754.

[17] Malysheva N., Prokof"ev A., Bubnov N. et al.: Izv. Akad. Nauk SSSR, Ser. Khim., 1977, 1522.

[18] PaQuette L. and Farley W.: J. Org. Chem., 1967, 32, 2718.

\section{2,6-ДИ-ТРЕТ-БУТИЛФЕНОЛЯТИКАЛЮ І НАТРІЮ ТА ЇХ ВЛАСТИВОСТІ}

Анотація. Показано, цио вирішальним чинником реакиіі 2,6-ди-трет-бутилфенолу з лужними металами $\epsilon$ температура, в залежності від якої утворюються два типи 2,6-ди-трет-бутилфенолятів калію або натрію з різною каталітичною активністю в реакиіях алкілування 2,6-дитрет-бутил фенолу з метилакрилатом. При температурах вищчих за $433 \mathrm{~K}$ синтезовано більш активні форми 2,6$\mathrm{Bu}_{2}{ }_{2} \mathrm{C}_{6} \mathrm{H}_{3} \mathrm{OK}$ або 2,6-Bu ${ }_{2} \mathrm{C}_{6} \mathrm{H}_{3} \mathrm{ONa}$. Циклогексадієнову структуру 2,6-Bu ${ }_{2}{ }_{2} \mathrm{C}_{6} \mathrm{H}_{3} \mathrm{OK} \mathrm{i} 2,6-\mathrm{Bu}_{2}{ }_{2} \mathrm{C}_{6} \mathrm{H}_{3} \mathrm{ONa}$ підтверджено методами ЯМР ${ }^{1} H$ електронної та IЧ-спектроскопї. Визначено, щзо у середовищі диметилформаміду або диметилсульфоксиду димерні форми 2,6-ди-трет-бутилфенолу реагують з метилакрилатом з утворенням метил 3-(4гідрокси-3,5-ди-трет-бутилфенил)пропіонату, вихід якого становить 64-92\%.

Ключові слова: феноли, феноляти, 2,6-ди-третбутилфенол, метилакрилат, кінетика, димери, гідроксид калію, гідроксид натрію. 